VoL. 75 (2007) [157-158]

\title{
Stochastic models of election timing
}

\author{
DHARMA LESMONO
}

Under the democratic systems of government installed in many sovereign states, the party in government maintains a constitutional right to call an early election. While the constitution states that there is a maximum period between elections, early elections are frequently called.

This right to call an early election gives the government a control to maximize its remaining life in power. The optimal control for the government is found by locating an exercise boundary that indicates whether or not a premature election should be called. This problem draws upon the body of literature on optimal stopping problems and stochastic control.

Morgan Poll's two-party-preferred data are used to model the behaviour of the poll process and a mean reverting Stochastic Differential Equation (SDE) is fitted to these data. Parameters of this SDE are estimated using the Maximum Likelihood Estimation (MLE) Method. Analytic analysis of the SDE for the poll process is given and it will be proven that there is a unique solution to the SDE subject to some conditions.

In the first layer, a discrete time model is developed by considering a binary control for the government, viz. calling an early election or not. A comparison between a threeyear and a four-year maximum term is also given. A condition when the early exercise option is removed, which leads to a fixed term government such as in the USA is also considered. In the next layer, the possibility for the government to use some control tools that are termed as 'boosts' to induce shocks to the opinion polls by making timely policy announcements or economic actions is also considered. These actions will improve the government's popularity and will have some impacts upon the early-election exercise boundary. An extension is also given by allowing the government to choose the size of its 'boosts' to maximize its expected remaining life in power.

In the next layer, a continuous time model for this election timing is developed by using a martingale approach and Ito's Lemma which leads to a problem of solving a partial differential equation (PDE) along with some boundary conditions.

Received 18th September, 2006

Thesis submitted to The Univeristy of Queensland, January 2006. Degree approved, July 2006. Supervisors: Professor Kevin Burrange, Dr Elliot Tonkes and Professor Phil Pollett.

Copyright Clearance Centre, Inc. Serial-fee code: 0004-9727/07 \$A2.00+0.00. 
Another condition considered is when the government can only call an election and the opposition can apply 'boosts' to raise its popularity or just to pull government's popularity down. The ultimate case analysed is when both the government and the opposition can use 'boosts' and the government still has option to call an early election. In these two cases a game theory approach is employed and results are given in terms of the expected remaining life in power and the probability of calling and using 'boosts' at every time step and at certain level of popularity.

Department of Mathematics

Parahyangan Catholic University

Jalan Ciumbuleuit 94

Bandung 40141

Indonesia 